\title{
SOBRE A VULNERABILIDADE SOCIOECONÔMICA E CIVIL Estados Unidos, França e Brasil ${ }^{*}$
}

\section{Lúcio Kowarick}

\section{Introdução}

A única unidade que é possível, portanto, reivindicar a respeito destes temas lexclusão, underclass e marginalidadel é que eles colocam em causa, só por sua presença, os princípios que fundamentam a ordem social.

Didier Fassin, 1996.

Este ensaio tem por objetivo analisar os significados de uma discussão que se apóia em temas e termos diversos nos Estados Unidos e na França, com comentários finais acerca da sociedade brasileira. Não pretendo fazer um estudo comparativo, pois trata-se antes de realizar o que pode

* Este artigo faz parte de um ensaio mais amplo: Kowarick (2001) A parte referente à sociedade brasileira foi publicada em Kowarick (2002). Na parte final deste artigo faço um resumo desta publicação para destacar alguns pontos sobre a atualidade do Brasil urbano.

Artigo recebido e aprovado em dezembro/2002. ser designado de olhares cruzados, captando o que há de essencial no debate acadêmico dessas sociedades. O tema diz respeito à vasta parcela daqueles que estão à margem, desligados ou desenraizados dos processos essenciais da sociedade. Trata-se daquilo que se convencionou denominar os excluídos, noção ampla e escorregadia que se tornou uso corrente e que necessita ser trabalhada empírica e teoricamente. É a trajetória desta questão que pretendo realizar, reafirmando que o intento é clarear o nebuloso e complexo debate acerca dos contingentes não incluídos nas cidades, mesmo porque as populações rurais fogem do escopo deste ensaio.

Não são poucos os estudos que discutem este tema de forma a cotejar os desafios interpretativos que decorrem de realidades nacionais distintas. ${ }^{1}$ Mas são raríssimos os que introduzem nesta discussão a produção latino-americana que tem início no final dos anos de 1960 (Fassin, 1996). 
Vale apontar que o debate norte-americano é abertamente político-ideológico. Isto porque os pesquisadores colocam seus críticos e criticados ou no campo conservador, ou no liberal, na acepção norte-americana do termo, isto é, progressista, pois inspirado nas tradições que fundamentam as políticas de bem-estar social. De um lado, blaming the victim, aberta e feroz culpabilização das pessoas que se encontram em precárias condições sociais e econômicas, pois, nessa vertente interpretativa, esta situação é vista como fruto de sua própria e única (ir)responsabilidade. Mais ainda: segundo essa visão, as políticas públicas só serviriam para reproduzir ou aumentar a anomia, a ociosidade e a indolência, a desestruturação familiar, o consumo de drogas e as várias formas de criminalidade. De outro lado, os liberais enfatizam que não é no comportamento ou nos valores do indivíduo que se deve buscar as causas do problema, mas nos processos estruturais amplos, na desindustrialização de determinadas regiões, nas transformações tecnológicas e gerenciais, nas mudanças no perfil da mão-de-obra, nas transformações sociais e urbanas das grandes cidades ou no secular preconceito racial que desaba, particularmente, sobre a população afro-americana. Como será detalhado, a hegemonia do pensamento liberal dos anos de 1960-1970 é superada pelo conservadorismo predominante na década de 1980. No decênio seguinte, com a administração Bill Clinton, fundamentalmente, no seu segundo mandato, com maioria parlamentar republicana, há uma aproximação dessas duas visões: as concepções liberais tradicionais que apregoavam a prerrogativa de direitos (entitlement) são solapadas pela noção de deveres e, em boa medida, passam também a responsabilizar os indivíduos por sua condição de vida. O conceito que alimenta o debate acadêmico e político até o início dos anos de 1990 é o de underclass, subclasse à margem da sociedade.

O debate francês, a seu turno, baseia-se em conceitos como exclusão, relegação, desqualificação ou desfiliação social. Afirma que não se trata apenas daqueles que não puderam pagar o preço do progresso, ficando à margem de uma sociedade que se modernizava, mas, cada vez mais, após os anos de 1980, também dos que ocupam posições centrais no sistema produtivo do qual foram desconectados: seguindo as trilhas da tradição republicana e jacobina, as análises, variando nos diagnósticos e nas propostas, enfatizam a necessidade de uma forte presença estatal, que tem como responsabilidade primeira fornecer os recursos materiais e culturais que promovam a (re)inserção social e econômica dos grupos marginalizados. O fundamento da própria democracia residiria na dinamização de formas de solidariedade que não deixassem aqueles que estivessem fora lá permanecer, pois isso significaria a reprodução das iniqüidades e injustiças que a ação estatal priorizou combater desde 1789 em nome da defesa dos direitos básicos de cidadania. Ação que foi aprofundada pelos socialistas e comunistas durante o Front Populaire de 1936 e, fundamentalmente, após a Segunda Grande Guerra.

Analisarei, inicialmente, o teor das discussões nos Estados Unidos para, em seguida, passar para o caso francês. A partir do que estou designando de olhares cruzados, na parte final deste artigo retomo alguns pontos sobre a sociedade brasileira. O objetivo deste ensaio não é efetuar um balanço crítico da literatura, mas, a partir de alguns textos seminais, mostrar os conteúdos e os contornos que a questão social adquire em função das especificidades próprias de cada ambiente sociopolítico nacional.

\section{A discussão norte-americana: culpar ou não culpar a vítima}

A mera existência de um sistema de bem-estar social [...] [tem] [...] como conseqüência inevitável minar o caráter moral do povo. Não trabalhar é mais fácil que trabalbar. Charles Murray, 1994.

\section{Liberais versus conservadores}

Underclass: subclasse, ou desclassificado, constitui uma questão amplamente pesquisada nos Estados Unidos. Vale dizer que a maioria dos estudos procura checar, apoiada em universos empíricos restritos - geralmente um gueto negro de 
cidades de médio ou grande porte -, os resultados emanados de abordagens mais abrangentes. Nesse sentido, os trabalhos de William Julius Wilson, sobretudo The Truly Disadvantaged, foram objeto de atenção de inúmeros estudiosos que procuraram testar os resultados de suas investigações: entre outras questões, as mudanças na oferta de emprego que começaram a ocorrer a partir da década de 1970, o declínio de taxas de casamento entre a população afro-americana e o decorrente aumento de famílias monoparentais com chefia feminina, a evasão dos estratos afro-descendentes abastados para fora dos guetos, a crescente concentração da pobreza, desemprego e dependência de serviços sociais e os efeitos desse tipo de vizinhança sobre os jovens no que concerne ao comportamento sexual, abandono da escola, consumo de drogas e aos atos delinqüentes. ${ }^{2}$

Sem penetrar em detalhes históricos, importa notar que a questão da pobreza sempre teve uma tônica fortemente ética, na qual os indivíduos que se encontravam nessa situação eram por ela responsabilizados, pois careciam de atributos como força de vontade e energia moral: "pauperismo diz um pregador no início do século XIX - é a conseqüência de erro intencional, indolência vergonhosa, hábitos viciosos" (Burroughs apud Katz, 1993 , p. 6). Insisto neste ponto, pois a forma de culpabilizar a pobreza, associando-a à indolência, à desorganização familiar e até mesmo à criminalidade, continua uma tônica dominante no debate norte-americano. Esse tipo de representação sociocultural parece estar ligado ao credo norte-americano que, ao beber nas águas do puritanismo da ética protestante e do espírito do capitalismo, elege o individualismo e a competição como atributos básicos para conquistar os benefícios de uma sociedade que se fundamenta em ideais igualitários, na independência e na iniciativa pessoal (Katz, idem, pp. 6-7). Nesse contexto que proclama a igualdade de oportunidades, a marginalização social e econômica passa a ser encarada como fraqueza peculiar a indivíduos ou grupos que, como tais, não possuem a perseverança ou o treinamento moral para vencer na vida. Nesse sentido, o dilema norte-americano estaria concentrado nas realidades e nas explicações da histórica margina- lização social e econômica das populações afroamericanas (Myrdal, 1994).

Nos percursos da história, várias denominações foram utilizadas para nomear essas subclasses, todas com conotações de cunho incriminador:

[...] pedinte, desvalido, classe perigosa, ralé, vagabundo e vadio, e assim por diante, [designações] que os Estados Unidos tomaram emprestado da Europa. A América também inventou seus próprios termos, incluindo-se preguiçoso, mendigo e idiota, e, no final do século XX, outros como, desqualificado, marginal, culturalmente deficiente, e, mais recentemente, underclass (Gans, 1994).

O termo underclass foi introduzido no início dos anos de1960 para designar o processo de marginalização do mercado de trabalho assalariado e formal que marginalizou uma parcela da mão-de-obra de baixa qualificação: utilizado no âmbito de uma interpretação progressista, apontava como causas desse fenômeno não os fatores sociopsicológicos próximos das pessoas inseridas na situação de desemprego ou subemprego, mas as grandes mudanças que marcaram a sociedade norte-americana no segundo pós-Guerra (Myrdal, 1963). A análise mostrava que as mudanças tecnológicas e organizacionais tornavam dispensáveis boa parte daqueles que não tinham capacitação profissional para enfrentar as inovações que as empresas passaram a exigir dos trabalhadores.

As interpretações presentes na obra de Gunnar Myrdal, The challenge to affluence, não culpabilizam as pessoas por seu insucesso, por terem ficado à margem da arrancada de mobilidade ascendente que marcou a sociedade norte-americana. Em outros termos, a afluência também marginalizava, o que se mostrou particularmente perverso para parte da população afro-descendente. Isso porque o circuito excludente se completava através do racismo e da segregação racial que recaíam sobre os contingentes dos guetos das grandes cidades. Esse livro representou uma poderosa oposição ao clima de otimismo imperante na época, expresso na sociedade de abundância, de John Kenneth Galbraith, ou no fim das ideologias, de Daniel Bell, constituindo-se em um veículo que serviu de alarme para implementar as políti- 
cas públicas de combate à pobreza dos governos democráticos dos anos de $1960 .^{3}$

Esta década foi cenário de enormes debates e embates sobre a questão da pobreza e da desigualdade de oportunidade. Do ponto de vista do ideário progressista, os estudos então realizados serviram de forte estímulo para fomentar políticas públicas que deveriam fornecer condições para retirar as camadas pobres de sua situação de anomia e marginalização. ${ }^{4}$ Vale ressaltar que em 1964 é promulgada a lei dos direitos civis referente à discriminação racial, ao mesmo tempo em que a administração democrata Lyndon Johnson faz aprovar pelo Congresso os programas conhecidos como War on Poverty que, ao privilegiarem políticas de proteção e integração social e econômica, deveriam acelerar a emergência da Great Society. ${ }^{5}$

Nesse contexto social e político é publicado o relatório Moynihan, confeccionado por um jovem assistente da Secretaria do Trabalho vinculado à Casa Branca.${ }^{6} \mathrm{O}$ trabalho ressaltava a crescente incidência entre a população afro-americana de desempregados, famílias monoparentais com chefia feminina, filhos ilegítimos e dependência dos serviços assistenciais, cuja conseqüência mais grave era a emergência do que foi então designado de "matriarcado negro". Nesse sentido, convém ressaltar que as lideranças dos direitos civis consideraram o relatório "ofensivo", "empiricamente falho", "difamante", "desviando a responsabilidade das causas da pobreza para suas vítimas" (Katz, 1993, p. 13). Esta foi uma época de violentos conflitos e manifestações anti-raciais que culminaram no assassinato de Martin Luther King e no surgimento dos "panteras negras", o que ocasionou o recuo dos liberais. A fim de escapar da pecha de racistas, deixaram de se debruçar sobre situações e comportamentos que caracterizavam de forma crescente os guetos da população afro-americana. Nesse clima de acirramento político-ideológico, as explicações centraram-se em causas como o racismo e a exploração econômica, deixando um vazio analítico que foi apropriado pelo pensamento conservador:

[...] se esta matriz de crítica ideológica desencorajou a pesquisa de estudiosos progressistas, os pensadores conservadores não ficaram inibidos. Desde os inícios da década de 1970 até a primeira metade dos anos de 1980, seus escritos sobre a cultura da pobreza e os efeitos deletérios da política progressista de bem-estar da Great Society sobre o comportamento da underclass dos guetos dominaram o debate acerca das políticas públicas no que diz respeito à diminuição dos problemas sociais das áreas centrais das cidades (Wilson, 1987, p. 150).

\section{Conservadores versus liberais}

As explicações conservadoras acerca dos habitantes afro-descendentes das grandes cidades tornaram-se hegemônicas por um longo período, coincidente com as administrações republicanas de Ronald Reagan e George Bush. Conservadoras porque, emprenhadas de conteúdos moralizadores, responsabilizavam as pessoas por sua condição de marginalização e anomia. O foco de análise privilegiava os componentes culturais, deixando de lado as dimensões estruturais dos problemas que afetavam estas populações: falava-se de carências culturais e comportamento deficiente - cultural and behavioral deficiencies - em vez de focalizar os macroprocessos que se enraizavam nas causas da marginalização social e econômica. Acusação de cunho moralista, pois se originava na "[...] ausência de ética do trabalho, valores familiares e religiosos, respeito pela lei e outros atributos invocados pela Nova Direita" (Silver, 1999, p. 345). Nesse tipo de abordagem, a parcela mais pobre dos grupos afroamericanos teria atitudes semelhantes ao refugar o trabalho e preferir a dependência dos serviços sociais. Uma obra pioneira que serviu para alimentar os estudos que enfatizaram a assim chamada welfare dependency foi a de Oscar Lewis (1961a, 1961b, 1965, 1966).

A partir de observação participante e de histórias de vida, Lewis constrói o conceito de cultura da pobreza, cujos traços essenciais seriam a resignação, a passividade, o fatalismo, o círculo de relações sociais restrito e pouco diferenciado, as respostas voltadas ao imediato, as aspirações limitadas e o sentimento de inferioridade. Esses traços 
forjariam um conjunto de valores, crenças e atitudes relativamente homogêneo, reproduzido de geração em geração, que se contrapunha ao referencial cultural dominante marcado pelo sucesso advindo de trajetórias de vida marcadamente competitivas. Não cabe, no âmbito deste ensaio, retomar as críticas feitas ao modelo analítico proposto em torno do conceito de cultura da pobreza (ver Kowarick, 1980, pp. 34-38). Importa, contudo, apontar que esses escritos tiveram em décadas posteriores uma enorme influência no que diz respeito às concepções e às políticas relativas à questão da marginalização social e econômica: "a cultura da pobreza tornou-se um eufemismo para a patologia dos pobres inúteis e uma explicação para a sua condição [...]" (Katz, 1993, p. 13). Tal concepção causou sérias conseqüências no que diz respeito ao encolhimento das políticas de bem-estar social nos governos republicanos dos anos de 1970 e 1980. Inspiradas numa espécie de "darwinismo social", afirmava-se que elas fomentavam a ociosidade e o pauperismo, na medida em que o subsídio público tornava desnecessário o trabalho regular. Em decorrência, esses grupos não deveriam "ser ajudados devido a suas patologias destrutivas e anti-sociais. Esqueça-se os fatores estruturais ou o generoso sistema de bem-estar: culpe a vítima" (Robinson e Gregson, 1992, p. 40).

$\mathrm{Na}$ esteira desse pensamento condenatório, deve ser ressaltado que o termo underclass foi amplamente popularizado através de longas reportagens que apareceram com destaque em revistas como Newsweek, Fortune ou Readers Digest. A tônica das apreciações não enfatizava a pobreza que se avolumava nos grandes centros urbanos ou a falta de oportunidade de ascensão que marcava o destino de milhões de pessoas, principalmente os afro-americanos, "mas a criminalidade violenta [...], a depravação moral, a sexualidade incontrolada das adolescentes filhas/ mães do gueto e o peso fiscal, julgado incontrolável, dos programas sociais instaurados pela pressão dos movimentos reivindicatórios dos anos de 1960" (Wacquant, 1996a, p. 245). Menção especial deve ser feita à revista Time, que em um dossiê de quatorze páginas caracterizava o american underclass como "pessoas que são mais in- tratáveis, mais socialmente alienadas e mais hostis [...]" (Russel, 1977, p. 18).

Contudo, foi sem dúvida com os escritos que apareceram em três números de enorme sucesso da revista New Yorker, depois transformado em livro - The Underclass -, que a palavra se popularizou, tornando-se tema de debate cotidiano, com um grande reflexo sobre a opinião pública e de extrema valia para fundamentar a desativação de políticas de bem-estar social das administrações republicanas. Vale transcrever uma longa citação do início dos anos de 1980, período de intensa recessão, conhecida como reaganomics:

[...] não há números precisos, mas estima-se que nove milhões de norte-americanos não são assimiláveis. Eles constituem a underclass. Em termos gerais, podem ser agrupados em quatro categorias distintas: (a) os pobres passivos, que, no mais das vezes, são recipientes de longo prazo de serviços sociais; (b) o hostil criminoso de rua, que aterroriza grande parte das cidades e que, geralmente, foi expulso da escola e é consumidor de droga; (c) o escroque (hustler), [...] que ganha a vida na economia subterrânea [...]; (d) os bêbados traumatizados, vagabundos, moradores de rua [...] e os doentes mentais, que, freqüentemente, vagueiam ou morrem nas ruas da cidade (Auletta, 1981, p. XVI).

O conservadorismo havia vencido, pois convencera a maioria dos eleitores que havia um grupo minoritário, porém numeroso, de desajustados, inúteis, ociosos e perigosos, enfim, uma subclasse desqualificada e imprestável para a qual as políticas públicas só serviram para reproduzir a indolência, a anomia e a propensão à criminalidade. Nesse particular, a obra Losing Ground, de Charles Murray (1994), é seminal. Ao analisar as políticas de bem-estar social, o autor parte da constatação de que o aumento do orçamento público entre 1950 e 1980 não havia levado à diminuição dos problemas sociais. Ao contrário, os índices de pobreza e desemprego, de famílias monoparentais chefiadas por mulheres, de filhos ilegítimos e gravidez de adolescentes aumentaram muito nos guetos negros, assim como as várias modalidades de violência e criminalidade. 
Em outras palavras, os programas dos anos de 1960, que se condensaram na assim chamada War on Poverty, tiveram resultados nefastos: agora, além de culpabilizar as vítimas, estava-se também atacando a "generosidade" dos governos do Partido Democrático. Generosidade que corroía a vontade de trabalhar, solapava a vida familiar estável e estimulava comportamentos ilegais. Isto porque, para a mão-de-obra braçal ou pouco qualificada, ficar desempregado não significava necessariamente ganhar menos e, no caso das mulheres, filhos ilegítimos poderiam representar ganhos superiores aos oferecidos pelo mercado de trabalho: a ajuda vinda principalmente do Aid To Families With Dependent Children - AFDC estimulava o desemprego voluntário e a desorganização familiar. Produziase, assim, por meio das políticas estatais, uma "cultura da dependência" ou de "parasitismo social" diametralmente oposta ao ideário norteamericano que cultiva aqueles que ganham bem com o esforço do trabalho, pagam impostos, educam os filhos nos padrões da moralidade dominante e participam do desenvolvimento da comunidade em que vivem.

No prefácio da $2 .^{a}$ edição, publicada em 1994, Charles Murray, após dizer que o livro sofreu "ataques selvagens da esquerda", enfatiza que

[...] atualmente é aceito que os programas sociais dos anos de 1960 de modo geral falharam; que o governo é grosseiro e inoperante quando interfere na vida local; e que os princípios de responsabilidade pessoal, penalidades para o mal comportamento e recompensas para o bom precisam ser reintroduzidos nas políticas sociais (p. XVI).

E mais adiante:

[a underclass] não tem os mesmos valores que a classe média referentes ao trabalho árduo, honestidade e responsabilidade pessoal. [...]. Há dez anos [eram poucos os estudos que associavam as políticas] de bem-estar com [nascimentos] ilegítimos. [...] Atualmente, eles se expandiram consideravelmente. Daqui a dez anos será amplamente aceito entre os pesquisadores que a existência de um extenso sistema de bem-estar constitui condição decisiva para facilitar a ilegitimidade (p. XVII).
O raciocínio do autor no que concerne a filhos ilegítimos está baseado na trama hipotética de dois jovens trabalhadores sem qualificação profissional - Harold and Phyllys - na qual, não estando casados, ela está grávida. Em 1950, quando inexistiam subsídios a mães solteiras, seguindo um cálculo racional, eles, supostamente, escolhem o casamento e a busca de remuneração por meio de inserção no mercado de trabalho. Dez anos depois, há subsídio para mães solteiras, e, portanto, nesse momento, a escolha lógica seria a de não se casarem. Já nos anos de 1970, a ajuda é maior do que o salário que Harold poderia obter na hipótese de não se casarem e, assim, enquanto ele opta por permanecer desempregado e não se casar, ela prefere continuar tendo filhos:

[na década de 1970] era mais fácil sobreviver sem ter um trabalho. Era mais fácil para o homem ter um filho sem ser responsável por ele, para a mulher ter um filho sem ter marido [...]. Porque era mais fácil sobreviver sem trabalho, era mais fácil ignorar a educação. Porque era mais fácil sobreviver desempregado, era mais fácil passar de um trabalho para outro e através disto acumular uma ficha de inempregável (p. 175).

Para os estudiosos progressistas da época era difícil contra-argumentar as colocações conservadoras que insistiam na culpabilização das vítimas e nos nefastos efeitos das políticas de bem-estar social em produzir a desnecessidade de trabalhar e a desorganização familiar: "deste ponto de vista, o 'sucesso' atual da noção de underclass como figura do undeserving poor só é o sucesso político dos conservadores" (Avanel, 1997, 217).

Isso não significa dizer que não houve autores que tenham se oposto aos modelos explicativos e às políticas conservadoras dos anos de $1980 .{ }^{8}$ Nesse particular, ganha relevância a obra de William Julius Wilson. Mesmo este autor, cujas pesquisas sobre a pobreza urbana são das mais reconhecidas no meio acadêmico, necessita explicitar, no prefácio de The Truly Disadvantaged, sua posição política: "eu sou um social democrata" (p. VIII). Isto porque, malgrado ser um pesquisador que se situa no campo progressista, em trabalho anterior, ao argumentar que a questão racial 
explicava cada vez menos a marginalização da população afro-americana, recebera, por essa razão, críticas que procuraram situar sua argumentação no espectro conservador do debate acerca da problemática sobre a underclass (p. 5). O teor da polêmica foi um exemplo flagrante de como o debate norte-americano era abertamente polarizado entre conservadores e liberais. Nas primeiras páginas da obra em pauta pode-se ler:

[...] gostaria de sugerir como a perspectiva liberal pode ser reforçada para colocar em xeque a atualmente dominante visão conservadora acerca do ghetto underclass e, mais importante do que isto, fornecer uma discussão intelectual mais equilibrada acerca do crescimento dos problemas das áreas centrais [...] [que concentram a população negra] (p. 11). [E, nesse sentido, Wilson vai insistir que] o racismo constitui uma explicação demasiadamente simples (p. 61)

Além do racismo, a explicação proposta pelo autor privilegia o processo de desindustrialização na maioria dos grandes centros urbanos, em que mudanças tecnológicas e organizacionais levaram à redução do trabalho pouco ou não-qualificado. Paradoxalmente, a expansão econômica e a universalização dos direitos civis dos anos de 1960 fizeram com que as camadas afro-americanas mais habilitadas para enfrentar as mudanças que ocorriam deixassem os guetos para irem trabalhar $\mathrm{e}$ morar em comunidades mais prósperas. Essa evasão foi desastrosa para os estratos negros que lá permaneceram, pois levou não só a uma maior concentração de pobreza, desemprego, desorganização familiar e anomia, como também a um isolamento que gerou graves conseqüências. A saída de indivíduos e instituições propulsoras de relações e oportunidades sociais e econômicas - escolas, igrejas, lojas e profissionais - acirrou a marginalização ante as pujantes dinâmicas que ocorriam na sociedade norte-americana: "o conceito teórico, portanto, não é cultura da pobreza, mas o isolamento social". ${ }^{\circ}$

Vale ressaltar que a ambigüidade do termo underclass e sua utilização acusatória fez com que o próprio Wilson, que havia defendido a utilização do conceito em Truly Disadvantaged, em agosto de 1990, no discurso oficial como presidente da Associação Americana de Sociologia, recomenda o seu abandono (1990). Em When work disappears (1997), o autor utiliza o termo raramente e de maneira crítica, preferindo a designação de jobless ghetto para conceituar os assim chamados novos pobres urbanos. ${ }^{10}$ A partir da década de 1990 são raros os pesquisadores progressistas que o utilizam, pois se tornou "um instrumento de acusação pública" (Wacquant, 1996a, p. 250). ${ }^{11}$

\section{Conservadorismo e novo liberalismo}

"America is back": coesão familiar, trabalho árduo, laços comunitários, esforço e responsabilidade individual, diminuição da ação estatal, crença no livre jogo do mercado, patriotismo. Eis algumas ênfases dos valores que caracterizam os discursos e as ações da hegemonia conservadora que se acentuam a partir dos governos Ronald Reagan e George Bush. No âmbito das políticas públicas, cabe destacar a lei de 1988, conhecida como Family Support Act -FSA, que altera as regras do Aid to Families with Dependent Children - AFDC: tratava-se de combater a permissividade dos subsídios públicos. O espírito do novo programa colocava em xeque o princípio de prerrogativas de direitos - entitlement -, pois a concepção de contrapartida passa a ser condição necessária para a obtenção de benefícios: deve "haver obrigações sociais da cidadania" (Mead, 1986)..$^{12}$ O clima social e político dominante na década de 1980 permite tornar explícito os pressupostos acerca da pobreza feminina, principalmente, a afro-descendente:

[...] eles implicam que as políticas de bem-estar causam ruptura familiar, que as mulheres pobres têm filhos para aumentar seus benefícios, que mulheres sem maridos são promíscuas e sexualmente irresponsáveis e que o casamento constituía uma estratégia eficiente de combate à pobreza para as mulheres sem recursos (Abramovitz e Withorn, 1998, p. 156).

A hegemonia do período republicano produziu novas concepções políticas que aproximaram 
liberais e conservadores no governo democrata subseqüente de Bill Clinton: end the welfare as we know it, frase da primeira campanha presidencial, sintetiza novos postulados neo-liberais que desembocam no estuário tradicional das premissas conservadoras e que, em meados dos anos de 1990, com a vitória republicana no Congresso, como será detalhado mais adiante, dará origem ao PROWORA - Personal Responsability and Work Opportunity Reconciliation Act. Seus pressupostos são a exigência da necessidade de trabalhar e o combate à desestruturação familiar, enquanto o benefício torna-se mais difícil de ser obtido, limitado no tempo e sujeito a constante verificação.

O elã liberal de promover grandes reformas consubstanciadas na War on Poverty da década de 1960 chegou ao fim, quando o próprio presidente Clinton declara que "the era of government is over". Mas não apenas mais mercado e menos Estado passaram a alimentar o inventário dos novos democratas, também os postulados progressistas tradicionais foram sendo solapados por concepções moralistas acerca dos comportamentos e dos valores da população pobre. A retórica conservadora triunfava na medida em que as entonações acusatórias relacionadas ao welfare dependency ganhavam suporte na opinião pública e traduziam-se em políticas governamentais. Em síntese, tratava-se do "colapso do liberalismo" (Noble, 1997, p. 135).

Vale insistir nas teclas da aproximação dos novos liberais com as entonações da ação e do pensamento das partituras conservadoras:

[...] o ataque sistemático nas políticas de bemestar teria sido outra rodada de reformas historicamente conservadoras se não tivesse sido aprovado com grande suporte liberal. Os legisladores "liberais", a media "liberal" e os cientistas sociais "liberais" apoiaram as reformas de maneira acrítica, justificaram seus ataques ou consentiram por meio do próprio silêncio (Abramovitz e Withorn, 1998, p. 152).

A pouco mencionei que o termo underclass tinha caído em desuso nos anos de 1990. Desuso relativo, pois o núcleo do pensamento conservador reforçou nas tintas que pintavam essas sub- classes urbanas em termos marcadamente patológicos e imorais. Nesse aspecto, novamente despontam os estudos de Charles Murray:

\begin{abstract}
Eles se comportam de maneira diferente de todos os demais [...]. O homem na família era incapaz de manter um trabalho por mais de algumas semanas. A crianças estavam negligenciadas e comportavam-se de forma grosseira, criando problemas nas escolas. Freqüentemente, os pais dessas crianças não eram casados. Alcoolismo e promiscuidade sexual eram comuns. Assim como o crime, pequeno ou grande. Esse tipo de comportamento é o que designo pelo termo underclass - que não é somente pobreza, mas uma forma de comportamento [...]. Dez anos atrás, eu não poderia ter escrito os parágrafos precedentes sem ter sido chamado de racista (Murray, 1996, pp. 91 e 100). ${ }^{13}$
\end{abstract}

A arrogância desse conservadorismo triunfalista, que radicalizou a culpabilização das vítimas, continuou no percurso dos anos de 1990 a suscitar fortes críticas. Para só citar algumas obras recentes: foram denunciadas novas modalidades de racismo que insistiam na falta de motivação por parte dos grupos afro-descendentes e, portanto, na inoperância do apoio público (Wilson, 1999, pp. 21 e seguintes). Contestou-se a inexistência de aspirações diversas entre camadas pobres e remediadas ou abastadas e que a questão da pobreza deveria ser equacionada em torno das diferenças de oportunidades socioeconômicas (Gans, 1994, caps. 1 e 2). Contudo, a argumentação dominante deixou de estar centrada nas análises macroestruturais - mudanças tecnológicas e organizacionais, desindustrialização, deteriorização e êxodo urbano, dinâmica das classes, preconceito racial, ou na questão feminina. Esses enfoques perderam grande parte de sua capacidade persuasiva na medida em que sucumbiram na avalanche explicativa que culpabilizava os pobres por sua situação. Em suma, nas palavras de um texto radical que mostra a capitulação dos novos liberais: "a direita venceu” (Abramovitz e Withorn, 1998, p. 173).

A trajetória do programa designado de Aid to Families with Dependent Children - AFDC pode dar uma visão da evolução das políticas públicas nos Estados Unidos. Criado em 1935 como uma medida de proteção às viúvas, foi ampliado 
durante a década de 1960, com a implementação da War or Poverty para famílias que tinham um ou dois desempregados, bem como para as monoparentais, principalmente, de mães solteiras. Essa política passa a ser extremamente criticada pelos conservadores e cada vez mais irá prevalecer a concepção de contrapartida para quem é ajudado pelo poder público. Como já mencionado, esse é o espírito da lei conhecida como Family Support Act de 1988, promulgada durante o governo de George Bush. Nela, o princípio de welfare é substituído pelo de workfare e learnfare, que se tornaram condições prévias para se obter auxílios. Bill Clinton não tem posição diversa: em 1994 é aprovada uma lei que substitui a AFDC pela TANF - Temporary Assistence for Needed Families, que possibilita uma ajuda de apenas dois anos consecutivos ou cinco no total, permitindo a cada Estado estipular o montante a ser despendido e legislar sobre as regras para a concessão de auxílio. Finalmente, a reforma de agosto de 1996, quando há maioria republicana, o $103^{\circ}$ Congresso, com a adesão de uma grande fatia dos democratas, aprova um novo Contract-with-America, o Personal Responsability and Work Opportunity Reconciliation Act - PROWORA, que torna a concessão de benefícios mais rígida, baseada na emulação da responsabilidade individual. Sua finalidade, ao extinguir a prerrogativa de direitos, é combater a assim designada welfare dependency.

Vale insistir na importância dessas mudanças:

Esta reforma [PROWORA] efetivamente destruiu a antiga presunção de sessenta anos de que as famílias com necessidade tinham "direito" às políticas de bem-estar social. Pela primeira vez, governos estaduais poderiam negar auxílio às mulheres pobres, mesmo quando se encontravam qualificadas segundo as regras de elegibilidade do programa. O novo nome para AFDC - Temporary Aid to Needed Families - assinala a intento dessas drásticas revisões (Abramovitz e Withorn, 1998, p. 159).

Repita-se quantas vezes necessário for: apesar de amortecida durante os anos de 1990, a discussão norte-americana continua centrada na questão da welfare dependency e, em última instância, em blaming or not blaming the victim.

\section{O debate na atualidade francesa: a responsabilidade do Estado}

Não se constrói cidadania sobre a inutilidade social. Robert Castel, 1995a.

\section{Os percursos da questão social}

Extraída de obra seminal, esta frase sintetiza a amplidão do debate francês. Sintetiza, ao contrário da polêmica norte-americana, que a extensa vulnerabilidade é de responsabilidade do Estado. De fato, com diagnósticos e propostas diversas, os diferentes partidos do espectro político francês, da esquerda à extrema direita, consideram ser função essencial da ação estatal combater a assim chamada exclusão social e econômica. Por outro lado, vultuosos recursos são alocados em áreas degredadas, os quartiers difficiles, que concentram contingentes de estrangeiros, mas também grande número de franceses que se encontram desempregados ou com tarefas precárias, onde é freqüente a desorganização familiar, o isolamento social e a delinqüência juvenil.

Vale dizer que nenhum agrupamento políti$\mathrm{co}$, sindical, técnico ou intelectual coloca em xeque a necessidade da atuação governamental: os debates e embates residem no que e como o Estado precisa atuar. Apesar de antigos, eles ganham novos contornos depois da Segunda Grande Guerra, no contexto de uma nação que recém expulsara os invasores nazistas e fizera as contas com os colaboracionistas de Vichy: era necessário reconstruí-la. Nesse sentido, aponte-se que, após 1945, inicia-se uma longa fase de crescimento, no qual os órgãos governamentais têm forte interferência econômica. São os "Trinta anos gloriosos", caracterizados pelo pleno emprego e pela extensão de uma gama de direitos que fundamenta a proteção social dos assalariados. Mais do que nunca se impulsiona a construção do Estado de bem-estar social - État Providence ou État Social.

É nesse contexto social e político que se tecem os fios da questão social da atualidade francesa. ${ }^{14}$ Sua problematização e as políticas sociais dela derivadas podem ser periodizadas em quatro grandes momentos. O primeiro, no esforço de re- 
construção do pós-guerra, estende-se até o fim dos anos de 1960 e o problema a ser atacado centra-se na moradia, principalmente, em prédios antigos que abrigam cortiços. Daí a palavra de ordem levada adiante pelo abade Pierre em 1965: "guerre au taudis"! Desencadeiam-se ações governamentais de renovação urbana, construção de grandes conjuntos, principalmente os HLM, habitação de aluguel moderado. Na mesma direção desse discurso católico, Jean Labbens, militante da Association Quart Monde - ATD, designação que se refere aos que não conseguiram se manter ou se tornar assalariados, denuncia as injustiças e clama por intervenções que incorporem os "esquecidos" do progresso (Labbens, 1969, 1978)..$^{15}$ É este também o posicionamento do abade Wrisinski, criador da citada entidade e dinamizador do movimento aide à toute détresse, ou seja, daqueles que não conseguiram acompanhar o dinamismo da sociedade industrial.

No segundo momento, já em meados dos anos de 1970, a problemática transborda o âmbito da moradia e dos deserdados da fortuna. É nessa conjuntura que o termo exclusão social, através do livro de René Lenoir (1974), secretário de Estado da Ação Social do governo Jacques Chirac, de filiação gaullista, começa a adquirir visibilidade ao instalar-se de forma ainda pouco ruidosa no universo discursivo da política e da imprensa. Malgrado a análise realçar os problemas pessoais em detrimento dos macroprocessos socioeconômicos, já se aponta para o fato de que o crescimento da riqueza em si não reduz os níveis de pobreza que se abate sobre os handicapés sociaux: doentes mentais, alcoólatras, deficientes físicos e mentais e uma gama de inadaptados que deveriam ser beneficiados por políticas específicas de proteção social. Trata-se de uma "outra França [...] à margem da normal [...] mas que, não obstante sua situação de excepcionalidade, constitui uma [...] gangrena que ameaça [...] o conjunto do corpo social" (Lenoir, 1974, pp. 10 e 36).

A partir da segunda metade da década de 1980, já não se diz mais os "expelidos pelo dinamismo do progresso", pois os diagnósticos e as proposições se calibram em torno do que se convencionou chamar de nova pobreza. ${ }^{16}$ Nova po- breza porque a vulnerabilidade deixa de afetar só os grupos periféricos para se tornar um problema que desaba sobre as camadas que ocupam os estratos inferiores da pirâmide social. Não é mais só a fímbria da sociedade, mas se trata agora também de suas bases:

Nos anos de 1980, o movimento de precarização
econômica e social afeta as pessoas de baixa qua-
lificação, os handicapés légers, grande número de
pessoas que, durante o período de expansão desig-
nado de "Trinta Gloriosos", tinha um emprego. A
participação na vida econômica e social torna-se,
para esses novos pobres, conjunturalmente aleató-
ria. Os mais dotados em capitais escolares e rela-
cionais permanecem, por um tempo ainda, poupa-
dos por essa nova pobreza (Frétigné 1999, p. 62).

Lenta e persistentemente a questão social adquire novas e amplas configurações, passando dos "esquecidos do crescimento" dos anos de 1970 para os menos preparados do decênio seguinte, para culminar em uma situação de extensa vulnerabilidade que, em sua plenitude, desponta no início da década de 1990. Em síntese, em vinte anos a questão social metamorfoseia-se de "anormais incapazes" para "normais inúteis" (Donzelot, 1996, p. 59). ${ }^{17}$ Ela passa a englobar também estratos com níveis mais elevados de instrução e qualificação, trabalhadores especializados e quadros profissionais que até então trilhavam carreiras estáveis e previsíveis, num percurso protegido por direitos que lhes propiciava a ascensão econômica e social e uma forte presença no cenário político. Inicia-se uma situação de vulnerabilidade advinda do desemprego e da precarização do trabalho, rebaixamento de status e da perda de raízes ligadas à sociabilidade primária. Trata-se de grandes e variados grupos de "excluídos", sobre os quais as ciências humanas produziram dezenas de investigações e inúmeras teorizações sobre essa sempre renovada questão social que passa a penetrar o centro dos debates jornalísticos e políticos.

Não pretendo fazer um balanço dessa vasta literatura, mas tão-somente apontar a caracterização feita por alguns autores que toca em pelo menos três pontos básicos interligados. O primeiro diz respeito à desnecessidade desses grupos para as 
dinâmicas econômicas. Cito apenas alguns autores: Jaques Donzelot e Philipe Estebe (1991, p. 26) falam em "normais inúteis", Robert Castel (1991, p. 154; 1993, p. 145), em "desestabilização dos estáveis". Serge Paugam (1991, pp. 6 ss.) alude ao "descrédito" que se abate sobre os que estão à margem, Vincent Gaujelac e Isabele Leonetti (1994, p. 4) sublinham a percepção de "inferioridade", de "identidade de ferida", Viviane Forrester (1997, p. 38) exagera acerca da "normalização da anulação social", enquanto Pierre Bourdieu (1993, pp. $487-$ 498), em magnífica obra coletiva, descreve o sofrimento físico e mental decorrente da extrema pobreza e nos revela o que significa "viver por um fio". ${ }^{18}$ Finalmente, há a temática referente à perda das identidades advinda do desenraizamento familiar e comunitário, à queda da participação em associações recreativas, sindicais e partidárias, processos que conduzem à apatia e ao isolamento em um cenário social e político marcado pela diminuição dos conflitos abrangentes, fragmentação dos atores sociais e diluição de interesses coletivos. É nesta acepção que Jacques Donzelot e Philipe Estebe (1991, p. 27) se referem às "não-forças sociais, esta classe de desclassificados", que Robert Castel (1985a, p. 427) acentua a "ausência de perspectivas para controlar o futuro", e que Pierre Rosanvallon (1995, p. 203) dirá: "os excluídos constituem, de fato, quase que por sua própria essência, uma não-classe".

Em suma: a questão social passa a ser marcada por um processo em massa de desenraizamento e vulnerabilidade social e econômica. O operário, antes sindicalizado e freqüentemente simpatizante ou militante de esquerda, comunista ou socialista, vivia em bairros densos de vida social e política, dos quais se destaca, por sua tradições e experiências de luta, a ceinture rouge, correspondente às áreas que rodeiam Paris (Brunet, 1980, 1981; Pronier, 1983; Fourcaut, 1986). Nelas ramificavam-se múltiplas formas de sociabilidade operário-popular em torno das associações de bairro e também nas horas de lazer, festas, esportes e no bistrot, onde se teciam redes de solidariedade que asseguravam uma proteção advinda da proximidade social das classes trabalhadoras (Magri e Topalov, 1990).
Seja pelo aumento do desemprego e trabalho precário, seja pela crise econômica pós-1975, pelas mudanças tecnológicas e organizacionais decorrentes do modo de acumulação flexível ou por inúmeras outras causas que não cabem aqui aprofundar, o importante a realçar é que esses mundos operário-populares se desfazem: neles, os conflitos e as reivindicações contrapunham-se a opositores visíveis - o Estado, a burguesia, o patronato - e a violência inerente a essas lutas construía significados e sentidos que visavam a alterar a balança dos benefícios e das riquezas, e não poucas vezes projetavam valores de uma nova sociedade. Dito de outra forma, é o momento da centralidade das classes trabalhadoras, sobretudo da operária, na hegemonização das lutas e das reivindicações socioeconômicas e políticas. Nas áreas em que as indústrias têxteis, metal-mecânica, automobilística, química ou siderúrgica fecharam suas portas, os moradores que puderam sair, assim o fizeram, lá permanecendo aqueles que não tinham a alternativa de partir destes bairros, que passaram a ser chamados de "difíceis" ou "sensíveis", para permanecer nas designações oficiais mais freqüentes. Nessa conjuntura acirrada nos anos de 1980 e 1990, desarticulam-se as formas associativas que sedimentavam identidades assentadas no trabalho assalariado e na vida comunitária: trata-se de um enorme processo que Castel denomina crise da sociedade salarial (Castel, 1995a, caps. 7 e 8).

Por outro lado, vale sublinhar que a assim chamada violência urbana passa a ser freqüente no cotidiano desses bairros, também designados de "relegados" (Delarue, 1991). ${ }^{19}$ São manifestações esparsas e descontínuas, um pipocar de depredação, brigas, pequenos delitos ou outros atos predatórios realizados por jovens, la galère. Traduzem sentimentos difusos de "ira", "ódio", "raiva" ou "tédio", "a chatice e o vazio da existência" que, em certas ocasiões, explodem nas banlieus, também chamadas de exílio: ${ }^{20}$ "eles se revoltam mas não reivindicam nada. Expressam pela rebelião um desespero" (Donzelot e Estebe, 1991, p. 38). Minguettes, periferia de Lyon, verão de 1981: logo após a vitória dos socialistas com a eleição de Mitterrand, numa conjuntu- 
ra política promissora às propostas da esquerda, jovens furtam e queimam automóveis de luxo, sob os olhares perplexos do país, que a tudo assiste ao vivo pela televisão, e de uma polícia que não sabe o que fazer. Não são delinqüentes, mas cometem pequenos delitos, são arruaceiros que em bandos perambulam sem rumo, consumidores de drogas, com baixo nível educacional, uns desempregados, outros trabalhando, saltitando de estágio em estágio profissional. Seus comportamentos caracterizam-se pela incivilidade e falta de civismo em relação à família, à escola, ao prédio e ao bairro em que vivem, onde se localizam grandes conjuntos habitacionais, freqüentemente degradados e depredados. Suas cóleras voltam-se contra os agentes públicos, professores, assistentes sociais e, sobretudo, contra a polícia. Ativismo que não se canaliza em reivindicações concretas, "nomadismo imóvel", pois, como um relógio, sempre volta para o mesmo ponto, "agitações sem objeto", já que suas energias não se calibram para superar problemas concretos: "zonear significa perambular na superfície das coisas, aprimorar-se em nada fazer, ir de um lugar a outro sem ir a lugar algum" (Castel, 1995b, p. 14). ${ }^{21}$

Tudo indica que a galera não se caracteriza por uma "cultura da pobreza" à la Oscar Lewis ou pelo "isolamento sociocultural" como William J. Wilson se refere aos inner cities ghettos underclass dos Estados Unidos, mas revela atitudes e comportamentos que já foram cunhados de "cultura do aleatório" (Rouleau Berger, 1992, apud Castel, 1995a, p. 411).22 Contudo, nessas áreas, não habitam apenas pessoas que vivem um processo de ruptura social e econômica, nem prevalecem a desesperança, a desordem ou um potencial crônico de agressão. Isso existe, sem dúvida, mas, como mostra a etnografia que se deteve no significado da vida nesses bairros, é também um espaço do trabalho, do estudo, das relações afetivas e - como não poderia deixar de ser - onde se arquitetam projetos e aspirações que combinam desânimo, desilusão, esperança e otimismo. ${ }^{23}$

A problemática urbana e a dos jovens tornaram-se, no decorrer da década de 1990, um dos eixos que norteiam a questão social. Nesse sentido, são exemplos a serem destacados o Développement Social de Quartier, de 1981, as Zones d'Education Prioritaires, no ano seguinte, o Comité Communal de la Prévention de la Délinquence, Délégation e Comité Interministerielle de la Ville, em 1988, que culminaram um ano depois no Ministère de la Ville, que coordena a ação de vários órgãos referentes à educação, à saúde, ao emprego, à reforma e ao planejamento urbano, além de programas específicos voltados a jovens, idosos, famílias numerosas ou de chefia feminina (Damon, 1997). Sabe-se que os bairros periféricos são diversos, bem como a população que lá habita (Vários autores, 1998). Não obstante essa constatação, as análises insistem na temática da "fratura urbana", da "cidade desfeita, quebrada e implodida", em síntese, da "sociedade incivil" (Donzelot, 1999, p. 97).

Repita-se quantas vezes necessário for: nesses locais ocorreu o esfacelamento do modo de vida de tradição operário-popular, decorrente de um processo de urbanização que criou os grandes e desumanos conjuntos habitacionaise do esvaziamento das atividades fabris e da capacidade organizativa de associações, sindicatos e partidos de esquerda. Nesses locais, onde "não se deve ir", o cotidiano é marcado por manifestações endêmicas de violência urbana. Utilizo longa citação de uma pesquisa que mergulhou no significado de habitar nessas periferias marcadas pela marginalização:

[Essas aglomerações são] os lugares onde não se vai jamais, a não ser quando lá se mora ou quando há razões imperiosas [...]. A violência volta-se contra aqueles que dividem o mesmo habitat, a mesma comunidade de destino. E, forçosamente, ela transborda para o exterior de maneira errática, não política, ela faz as famílias implodirem [...]. São também locais em que bombeiros, policiais e trabalhadores sociais ou outros visitantes não podem mais ir sem ser insultados ou agredidos [...] não podem mais deixar seus automóveis. [É onde] a lei do silêncio reina sobre os atos cometidos de uns contra os outros, quando a vingança privada suplanta a sanção pública (Murard, 1995, pp. 203, 207 e 217). 


\section{A presença do Estado}

Afirmei que foram inúmeros os autores que trataram deste complexo tema, utilizando conceitos os mais diversos. Para mencionar apenas alguns: desqualificação social, que indica os rejeitados do processo produtivo e suas conseqüências socioculturais, ou desinserção, caracterizada pelo enfraquecimento dos laços relacionais e por uma identidade (auto)estigmatizante que acaba por induzir ao retraimento, à resignação ou à rebeldia. ${ }^{24}$ Aponto também as colocações de Alain Touraine, segundo as quais a oposição "no alto ou em baixo" teria sido uma hierarquização típica das sociedades industriais estruturadas na dinâmica das classes sociais e superada pelos solavancos das sociedades pós-modernas. Nelas, as estruturações sociais e econômicas estariam assentadas na dicotomia de setores in e out, pois a verticalidade das polarizações teria sido suplantada por aquela de caráter horizontal, isto é, estar ou não nas banlieus (Touraine, 1992; 1991).

Não obstante tais contribuições, considero, contudo, que a obra de maior envergadura histórica e teórica é a de Robert Castel:

[...] silhuetas incertas às margens do trabalho $\mathrm{e}$ nas bordas das formas de troca socialmente consagradas - desempregados de longa duração, habitantes das periferias deserdadas, beneficiários da renda mínima de inserção, vítima das renconversões industriais, jovens em busca de emprego e que perambulam de um estágio a outro, pequenas tarefas em ocupação provisória - quem são eles, de onde vêm, como chegaram lá, o que irão se tornar? (1995a, p. 13). ${ }^{25}$

Situações as mais diversas: ex-operários que possuíam uma profissão, idosos que vivem retirados no seu isolamento, bandos de jovens que vagueiam sem nada fazer. Essas trajetórias nada têm em comum e seus destinos não os unem, salvo a existência vulnerável, a percepção de um destino incerto: desfiliação significa perda de raízes sociais e econômicas e situa-se no universo semântico dos que foram desligados, desatados, desamarrados, transformados em sobrantes, inúteis e desabilitados socialmente. ${ }^{26}$ Não se trata, alerta o autor, de um estado ou de uma condição, mas de um percurso que é preciso constantemente perseguir para delinear suas múltiplas metamorfoses, pois a questão social só pode ser equacionada do ponto de vista histórico, por conseguinte, dinâmico, mutável e contraditório. Daí o título do livro: Les métamorphoses, "metamorfoses, dialética do mesmo e do diferente [...]. A questão social é uma aporia fundamental sobre a qual uma sociedade experimenta o enigma de sua coesão e procura conjurar o risco de sua fratura" (1995a, pp. 16 e 18, grifos meus).

De modo esquemático, o modelo formal está apoiado em dois eixos, um de caráter econômico, e outro, social, representados pelas trajetórias, respectivamente, do emprego estável e regular para modalidades de trabalho precário até atingir a situação de desemprego, e da plena inserção na sociabilidade primária - família, vizinhança, comunidade -, marcada por sólidas redes sociais ao retraimento do universo domiciliar/pessoal, definido pela fragilização das relações. Daí surgem quatro zonas: de integração, caracterizada por garantias de um trabalho permanente e por relações sociais sólidas; de vulnerabilidade, que conjuga precariedade no trabalho e fragilização da sociabilidade primária; de assistência, que revela um quadro no qual várias formas de subsídio público se tornaram imprescindíveis para não ocorrer uma dinâmica de desligamento social e econômico; e, por fim, de desfiliação, que significa não só desemprego, mas também perda das raízes forjadas no cotidiano do trabalho, do bairro ou da vida associativa. "Atualmente [início da década de 1990] a zona de integração se fratura, a zona de vulnerabilidade está em expansão e alimenta continuamente à zona de desfiliação. O único recurso reside em reforçar no mesmo ritmo a zona de assistência?" (Castel, 1991, p. 153).

Indivíduos desenraizados sempre existiram e sobre estes errantes de séculos passados desabava uma representação flagrantemente discriminatória e estigmatizante. Sobre as ditas "profissões infames" despencavam a pecha vadiagem, malandragem, charlatanice ou patifaria, e, no decorrer da história, várias foram suas designações: "indigentes franceses, malfeitores ingleses, aventurei- 
ros na Alemanha, pícaros espanhóis, larápios, velhacos, excluídos, mendigos, rufiões, truões, malandros, malabaristas, farsantes, devassos, luxuriosos e rameiras [...]" (Castel, 1999, p. 33).

Esses segmentos marginais não devem ser confundidos com aqueles que se encontram em uma condição de exclusão. Trata-se de uma diferenciação conceitual crucial, porque a noção de exclusão, além de estar saturada de significação, traz consigo a idéia de uma dicotomia estática e, portanto, a-histórica (Castel, 1995a, p. 15). É também crucial, pois se sabe que, já no século XIV, a palavra esteve associada à idéia de não ser admitido, repelido ou de ser mandado embora. Posteriormente, seu significado passa a designar alguém que se encontra desprovido de direitos (Rey, 1992, apud Frétighé, 1999, p. 151); ou seja, significa cercear, separar ou confinar, cujos exemplos são o apartheid, da África do Sul, até recentemente, ou os negros norte-americanos que até os anos de 1960 em Estados do Sul eram impedidos de entrar em determinados locais. Pode ter, além disso, o sentido de banimento, cujo exemplo clássico foi a expulsão de judeus e mouriscos da Espanha dos reis católicos, que obrigaram sua conversão ao catolicismo ou, em contrapartida, o exílio. Restrição de acesso, confinamento ou expatriação supõe um ato que tenha força legal, até mesmo em situações extremas de extermínio, sejam os considerados heréticos pela Santa Inquisição, seja os judeus e ciganos na Alemanha nazista. Não se trata, portanto, de desfiliação, que significa fragilização de laços socioeconômicos, mas de destituição de direitos que, em última instância, pode atingir, seguindo o pensamento de Hannah Arendt, a perda do direito de ter direitos (Castel, 1995b, pp. 18-19).

Por conseguinte, a questão social, que caracteriza a crise da sociedade salarial, reside num amplo e variado processo de vulnerabilidade, mas não revela, no caso francês, uma situação de exclusão nos vários graus e tipos antes apontados. Ela é fruto de um percorrer histórico que leva à ampliação e à consolidação de direitos coletivos, relativos à seguridade social e ao trabalho, enfim, à constituição de um campo legítimo e legal de reivindicações em que os opositores se chocam nos conflitos e aceitam as regras de sua negociação. Trata-se de um embate institucionalizado que visa à expansão do direito a ter direitos. Ela é, ademais, forjada pela chamada cultura do pobre, na acepção que Richard Hoggart (1970) confere à percepção de pertencer a valores e expectativas, a sociabilidade que aproxima as pessoas numa metamorfose que entrecruza o mundo do trabalho com comunidade de bairro. A sociedade salarial é também constituída pela formação das classes trabalhadoras - da qual nos fala Edward P. Thompson (1997) -, apoiada nas tradições que lapidam mútuos reconbecimentos e experiências compartilhadas. ${ }^{27}$

A dignificação do trabalho assalariado é um tortuoso percurso que atravessa todo o século XIX e parte do século XX. De forma sumária, pode-se dizer que começa a se configurar após 1830 uma nova questão social que se circunscreve em torno do pauperismo imperante com o avanço da Revolução Industrial. A liberdade de contratação vigente produziu uma mão-de-obra mal-remunerada, freqüentemente mutilada por acidentes e dilapidada prematuramente pelas longas jornadas de trabalho que caracterizavam as chamadas satanic mills. Basta ler Os miseráveis, de Vitor Hugo, para se ter um quadro do rigor e dos horrores vinculados ao trabalho assalariado e à moradia em bairros pobres, onde predominavam a insalubridade e a promiscuidade da vida nos cortiços e também se concentravam as "classes perigosas" dos inícios do século XIX.

A questão social da época residia em regulamentar as condições de trabalho quanto à remuneração, à jornada e à segurança e em criar um leque de proteção social para aqueles que ficassem sem emprego. Basta a análise do processo que leva ao reconhecimento do desempregado para se perceber que a construção da sociedade salarial é plena de conflitos e negociações que produzem o reconhecimento público do assalariado como sujeito de direitos coletivos (Topalov, 1994): férias remuneradas, convenções coletivas e jornada de quarenta horas semanais, em 1936, leis da moderna seguridade social, após a Segunda Grande Guerra, e salário mínimo, em 1950, são degraus que edificam a sociedade salarial, ao 
passo que o controvertido contrato individual referente à renda mínima de inserção - RMI, de 1988 - e à redução da jornada de trabalho para 35 horas semanais, promulgada em 2000, já são expressões da crise que se alastra a partir da década de 1980:

[...] da mesma forma que o pauperismo do século XIX estava inscrito no coração da dinâmica da primeira industrialização [...] a precarização do trabalho é um processo central, comandado por novas exigências técnico-econômicas do capitalismo moderno. Nisso residem muitos pontos para levantar uma nova questão social, com a mesma amplitude e a mesma centralidade que aquela que o pauperismo colocava na primeira metade do século XIX [...] (Castel, 1995a, pp. 409-410).

Repita-se ainda uma vez: quero crer que a questão social na França deve ser equacionada no âmbito da tradição republicana que se assenta do ângulo que aqui cabe salientar - em uma poderosa maquinaria pública de proteção e regulação econômica e social. Trata-se de instâncias de mediação de interesses conflitantes que têm por objetivo produzir um campo institucional de direitos e obrigações. Além de republicana, é também jacobina, no sentido de se opor a privilégios, e de esquerda, posto que, desde o século XIX, bebeu nas águas do sindicalismo e do mutualismo operário, e que, no século XX, valeu-se dos partidos e dos sindicatos comunistas e socialistas, que exerceram um papel decisivo na formatação do Estado de Bem-Estar já no período entre as duas Grandes Guerras Mundiais. Assim, penso ser possível afirmar que a problemática central do atual sistema político francês reside em gerar instâncias de combate à vulnerabilidade econômica, social e urbana. Não é por outra razão que a forte presença da ação pública, ao procurar mediar formas de solidariedade, encontra-se em outro universo da tradição do individualismo norteamericano, apoiada na valorização da work etbics e nos perigos, não raramente persecutórios, da welfare dependency:

[...] exclusão [é] uma palavra-chave da retórica republicana francesa. Não só ela se origina na França, mas também está ancorada na interpreta- ção da história republicana revolucionária francesa e do pensamento republicano. Desse ponto de vista, a exclusão não é concebida como um simples fenômeno econômico ou político, mas como uma falta de "nacionalidade", um esgarçamento do tecido social (Siver, 1994, pp. 591-592, grifos meus).

Essa problemática está presente no discurso político oficial há algumas décadas. Contudo, o termo "exclusão", no sentido forte de garantir a coesão social, só aparece no âmago do aparelho do Estado em 1991. É quando o Comissariat Général du Plan assume a responsabilidade de promover a inclusão dos segmentos em situação de vulnerabilidade, destacando a cidade, a escola, o emprego e a proteção social, pois os bairros periféricos, os jovens que não acompanham a seriação educacional, os desempregados de longa duração e aqueles que necessitam de assistência despontavam como questões sociais que colocavam em xeque a solidariedade social da sociedade francesa (Fassin, 1996, pp. 43-44).

Desde então o debate penetra no coração dos embates e debates políticos, despontando como prioridade nacional que articula plataformas eleitorais e políticas de várias instâncias de governo: a fracture sociale está no centro da campanha de 1995, quando a direita, com Jacques Chirac, ganha as eleições, assim como dois anos depois, ocasião em que os socialistas, liderados por Leonel Jospin, conseguem a vitória eleitoral: aquele aposta na dinamização da atividade econômica e este - vale lembrar - prescreve a diminuição da jornada de trabalho para 35 horas semanais. Na extrema direita, Jean Marie Le Pen, no seu Appel aux Français, impregnado de racismo e xenofobia, também prioriza o combate à pobreza e à desigualdade, vociferando contra a presença de estrangeiros em solo pátrio: o neo-fascista fala em extirpar a França dos males alienígenas que a contaminam para devolvê-la aos verdadeiros franceses. É também assunto central da grande imprensa que o aborda em termos indignados, pois considera o alijamento social e econômico em massa verdadeira "vergonha nacional". Como exemplo: "uma sociedade desenvolvida não pode viver com semelhante fratura e tolerar que uma 
parte importante de sua população arruíne sua coesão social". ${ }^{28}$

Para terminar este tópico, convém mencionar algumas ações governamentais para os anos 2000-2006 centradas na Gestion Publique de la Politique de Ville, do governo de Jospin, dirigidas prioritariamente para a renovação urbana, o emprego, o desenvolvimento, a educação e a segurança pública. Trata-se de uma intervenção coordenada a partir de contratos realizados com o Estado em 1.310 bairros prioritários, 750 zonas urbanas sensíveis (ZUS), outras 416 de redinamização urbana (ZRU), 44 denominadas franquia urbana (ZFU), nas quais ocorrem isenções de impostos e de encargos sociais. Acrescente-se ainda trinta operações de renovação urbana e cinqüenta grandes projetos para cidades (GPV), 686 zonas de educação prioritária (ZEP), 850 conselhos comunais de prevenção da delinqüência (CCPD) e nada menos que 8.500 agentes locais de mediação social, especialmente treinados para múltiplas atuações no âmbito comunitário. ${ }^{29}$

Esse conjunto de atuações interligadas constitui uma entre muitas formas de intervenção das instâncias públicas no combate da assim denominada "fratura social". Não estou discutindo se a forma mais adequada de reinserção socioeconômica seja por meio da questão urbana, apoiada na dinâmica do bairro, pois sabe-se que os processos essenciais da precarização e da vulnerabilidade não estão centrados no âmbito local (Préteceille, 1998, p. 42). Deve-se até mesmo questionar essas políticas caso estejam orientadas por uma concepção de segurança pública, que visa, por meio de órgãos assistências, jurídicos e policiais, a combater a pequena delinqüência praticada por jovens nas ruas dos bairros sensiveis ou difíceis, fazendo com que "a prevenção estrutural desaparecesse em proveito da prevenção da delinqüência" (Bonelli, 2001, p. 20). Contudo, à diferença do caso norte-americano, o republicanismo francês sempre priorizou a ação estatal como mediadora de interesses e conflitos e, nesse sentido, criou aparatos que lhe conferem a responsabilidade de agir contra a marginalização social e econômica. Os embates e debates não se centram, portanto, na polaridade "culpar ou não culpar as vítimas" - ponto modal da controvérsia norte-americana -, mas de criar instâncias públicas que interfiram nessas situações e nas causas que as produzam.

Nesse aspecto, a renda mínima de inserção (RMI) é paradigmática, pois o núcleo do debate não reside no fato de ela provocar uma "cultura da inatividade". Ao contrário, as críticas dominantes são dirigidas por ela não ser um direito de caráter inquestionável e apresentar a formalização de um contrato individual, constantemente submetido a questionamentos de entrevistas ministradas por agentes dos serviços sociais. Para ter acesso a esse direito, a pessoa necessita comprovar sua "desabilitação social" advinda de uma trajetória de vida estilhaçada por sofrimento e fracassos e que precisa ser retomada por meio de um projeto pessoal alicerçado na formação e na capacitação profissional, na busca de um emprego ou de outra atividade social. ${ }^{30}$ Contudo, à diferença da concepção norte-americana, prevalece o princípio de prerrogativa de direitos: as políticas sociais orientam-se para reinserir os grupos marginalizados, mas não constituem contrapartida necessária para a obtenção de benefícios. Em síntese, trata-se de um direito universal e, portanto, ao contrário da responsabilização individual presente nos Estados Unidos, a fórmula republicana francesa consiste em afirmar que "todo problema social do indivíduo é, antes de tudo, responsabilidade da sociedade, que o indivíduo sofre os efeitos da sociedade, e esta, portanto, lhe deve proteção" (Donzelot, 2001, p. 223).

Essas são as linhas básicas do debate acerca da questão social na atualidade francesa, na qual a presença da ação estatal continua estratégica e prioritária para a reinserção dos grupos vulneráveis.

\section{E nós, como ficamos? ${ }^{31}$}

Neste sentido ela [a pobreza] tem sim uma finalidade, qual seja a de reproduzir a ordem social que é sua desgraça. Como ficamos? Roberto Schwarz, 1990.

Nas páginas anteriores mostrei que a temática da vulnerabilidade está centrada, no caso norte-americano, em culpar ou não culpar a vítima. 
O discurso hegemônico que os conservadores vêm proferindo nos últimos vinte anos apregoa que os serviços sociais estariam quebrando a ética do esforço e da responsabilidade individual ao instalar o que chamam de welfare dependency. No caso francês, ao contrário, em função da forte tradição republicana e jacobina estruturada na crença sobre as virtudes da civilidade e do civismo que fundamentam os laços de solidariedade entre os diversos interesses e reivindicações, o debate, à esquerda ou à direita, torna o Estado elemento central na promoção da re-inclusão dos grupos marginalizados ou desfiliados.

E nós, como ficamos? A pergunta ganha sentido quando se tem em conta que as grandes transformações socioeconômicas e políticas das últimas décadas não foram capazes de atenuar a pobreza em massa imperante na sociedade brasileira. Em outros termos, quais discursos e ações dão conteúdo e forma às questôes sociais de nossa atualidade urbana em torno da problemática da desigualdade e da injustiça?

Diferentemente da estruturação discursiva norte-americana, creio que a matriz da desigualdade da sociedade brasileira não reside em culpar os pobres por sua pobreza, apesar de o discurso sobre a vadiagem ter estado muito presente em vários momentos da nossa história colonial, imperial e republicana. Contudo, a magnitude do pauperismo, na atualidade de nossas cidades, aparece de forma tão evidente que impede, cada vez mais, a afirmação de que vivemos em uma sociedade aberta e competitiva, onde quem trabalha duro e arduamente consegue ter êxito. Mesmo porque o desemprego, o subemprego e a precarização do trabalho atingiram também parcelas importantes das camadas médias. O mito da ascensão social pelo esforço e perseverança não encontra mais raízes para fundamentar o ideário da escalada social. Ao contrário, o trabalhador honesto, cumpridor de seus deveres - ante os ganhos provenientes de atividades ilícitas e ilegais - é visto não poucas vezes como "o otário que labora cada vez mais para ganhar cada vez menos" (Valladares, 1994, p. 107).

Por outro lado, inversamente aos embates e debates da sociedade francesa, o problema da po- breza passa a ser menos atribuído como de responsabilidade do Estado, mesmo porque a ação pública de proteção sempre foi de pequena envergadura. Além disso, atualmente, ganha corpo a percepção de que o Estado seja inoperante, ineficaz, corrupto, falido e que suas funções devam ser reduzidas e substituídas por agentes privados, mais capacitados para enfrentar as várias manifestações da marginalização social e econômica. Em conseqüência, tem ocorrido um amplo e diverso processo de desresponsabilização do Estado em relação aos direitos de cidadania, e, no seu lugar, surgem ações de cunho humanitário que tendem a equacionar as questões da pobreza em termos de atendimento particularizado e local.

Não desconheço as potencialidades de novas arenas que podem vir a estruturar campos de proteção e lutas por direitos socioeconômicos e civis, cujos exemplos mais promissores constituem o estatuto legal de defesa das crianças e adolescentes, das mulheres, dos consumidores ou a recente legislação que procura enfrentar os graves problemas urbanos de nossas cidades. Todos esses esforços, não obstante abrirem canais de defesa e reivindicação, são ainda embrionários, o que sustenta a ocorrência de amplo e variado processo de destituição de direitos.

Penso que tal processo tem pelo menos duas matrizes de atuação diversas, mas articuladas entre si. A primeira é clássica, e pode ser designada de controle e acomodação social pela naturalização dos acontecimentos. Ao invés de culpabilizar os pobres, os mecanismos residem justamente em desresponsabilizá-los da situação em que foram lançados por acaso, sorte ou azar que despenca aleatoriamente sobre uns e não sobre outros. Trata-se de discursos da imponderabilidade que seguem as leis incontroláveis da natureza ou a inevitabilidade daquilo que é assim porque assim sempre foi. A atualização desses equacionamentos proclama as leis inescapáveis do mercado, da globalização, do avanço tecnológico ou da hierarquização social e, dessa forma, acaba por levar à individualização da questão do pauperismo. Estar desempregado, morar em favela ou ser assassinado pela polícia ou por bandidos é equacionado como uma sina que cai sobre os deserdados da 
sorte: trata-se, enfim, de um "coitado". ${ }^{32}$ Em conseqüência, não só quem está no comando da relação social se desobriga dos que estão em posição de subalternidade, mas também a própria dinâmica que produz a marginalização ganha a nebulosidade do descompromisso, pois, segundo esse raciocínio, ela é também tida e havida como inelutavelmente natural: "tornando o pobre um 'não sujeito', a pobreza é como que 'naturalizada' e as relações sociais tornam-se 'naturalmente' excludentes" (Nascimento, 1994, p. 301). ${ }^{33}$

A outra matriz de controle e acomodação social pode ser designada de neutralização. Baseiase tanto em ardilosos artifícios de persuasão, como em escancarados métodos de constrangimento e coação que conformam mecanismos para reforçar as dinâmicas de subalternização. Inicio esta colocação aludindo ao tradicional ditado, não tão popular, que afirma que as pessoas devem permanecer nos seus devidos lugares - "cada macaco no seu galho". Trata-se de uma forma de discriminação escrachadamente marginalizadora e, com certeza, de difícil aplicação, pelo menos nos grandes centros urbanos. Mas há outras maneiras de demarcar o espaço social dos pobres. Basta observar nos edifícios das camadas remediadas e abastadas a existência de elevadores "sociais", para os proprietários, e os de "serviço", que, como sabemos, não se prestam apenas para a entrega de mercadorias. Esse pequeno exemplo revela a potência de nossas adocicadas formas de marginalização, afinal, neste país ninguém se considera preconceituoso, mas somos capazes muitas vezes de mantermos amizade com pessoas que manifestam restrições refletidas ou explosivas aos que são diferentes de sua e nossa cor ou condição social (Schwarcz, 2001).

Nessa direção, encontram-se os mecanismos de evitação e apartação presentes na sociabilidade cotidiana (Caldeira, 1997, pp. 142 ss.). Além disso, humilhação, extorsão, agressão, espancamento ou até mesmo homicídio, são atos cotidianos praticados tanto pela polícia como por bandidos, que permanecem ausentes das estatísticas, pois as pessoas, por medo de represália, se calam. Tal prática acaba por se tornar uma eficiente forma de controle e de acomodação social, na medi- da em que induz à idéia de que sair do seu "devido" lugar se trata de um ato bastante arriscado: "este brasileiro faz parte da comunidade política nacional apenas nominalmente. Seus direitos civis são desrespeitados sistematicamente. Ele é culpado até prova em contrário. Às vezes mesmo após provar em contrário" (Carvalho, s. d., p. 92).

Destacam-se nessa linha teórica as análises de Wanderley Guilherme dos Santos em polêmica categorização, segundo a qual em nosso tropicalismo exuberante há apenas natureza, uma espécie de hobbesianismo social, pois as pessoas se encontram isoladas e enredadas por sociabilidades fragilizadas, temem a convivência, desconfiam e desacreditam das instituições jurídicas e policiais e, em conseqüência, negam e sonegam os conflitos e as variadas modalidades de vitimização a que freqüentemente são submetidas: trata-se da cultura cívica da dissimulação (1994, pp. 100 ss., grifos meus). Francisco de Oliveira, em ensaio empolgante por sua radicalidade, refere-se à destituição, ao roubo ou à anulação de fala, isto é, à desclassificação dos conflitos e das reivindicações das classes dominadas (1999, pp. 55-81, grifos meus). Penso que é também nesta trilha interpretativa que se encaixam os argumentos de José de Souza Martins, quando indica a existência de dois mundos cada vez mais irredutíveis, onde as pessoas se encontram "separadas em estamentos": a modernidade brasileira estaria produzindo "uma espécie de sociedade de tipo feudal" (Martins, 1997, p. 36, grifos meus).

Estas reflexões não ignoram que os grupos, as categorias e as classes sociais se movimentam no sentido de se mobilizarem e lutarem pela conquista de seus direitos. Enfatizam, simplesmente, que no cenário atual de nossas cidades estão em curso vastos processos de vulnerabilidade socioeconômica e civil que conduzem ao que pode ser designado de processo de descidadanização.

Como sugerido na introdução desse ensaio, a questão da vulnerabilidade apresenta especificidades nos Estados Unidos, França e Brasil na maneira tanto de diagnosticar o problema, como de implementar as políticas públicas. O debate acadêmico, por conseguinte, reflete os impasses e os desafios das diversas conjunturas políticas nacionais. 


\section{NOTAS}

1 A título de exemplo, vale citar Silver (1999, pp.336354; 1996, pp. 105-138); Avenel (1997); Procacci (1996); Wacquant (1996b). Ver também vários artigos publicados em Donzelot e Jaillet (2001), principalmente, a parte II, "La Politique de la Ville, Une Comparaison entre les USA et la France".

2 Ver Wilson (1987). Uma das muitas avaliações críticas ao trabalho de Wilson pode ser encontrada na coletânia editada por Jenks e Peterson (1991), ou no excelente artigo de Katz (1993). Ver também Wilson (1992).

3 Ver Wacquant (1996a).

4 Entre outros, ver o influente livro de Harrington (1962).

5 Para uma análise desses programas, ver Wilson (1987), principalmente, os capítulos 6 e 7.

6 Moynihan (1965), posteriormente publicado em Rainwater e Yancey (1967).

7 Vale insistir neste ponto: "o crescente antagonismo foi ainda mais agravado pela atmosfera política conservadora, particularmente durante a presidência Reagan, que não só reforçou o sistema de crenças americanas segundo o qual a pobreza é reflexo de inadequações individuais, mas também desencorajou iniciativas para novos e mais vigorosos programas sociais dirigidos aos crescentes problemas de desigualdade urbana" (Wilson, 1991-1992, p. 65).

8 Entre outros, ver Ryan (1976); Jenks (1985); Wacquant (1996a); Marks (1991); Heisler (1991); Wilson (1987, principalmente, capítulo 4, escrito em conjunto com Aponte e Neckerman). Ver também Wilson (1993).

9 O autor refere-se ao Social Buffe, espécie de aparador ou colchão social que dinamizava a vida nos guetos e constituía um elo com os circuitos que serviam de canais para o processo de mobilidade ascendente. Idem, pp.56 e seguintes.

10 Em sua obra mais recente (Wilson, 1999), o termo nem aparece.

11 A principal exceção talvez seja Gans (1995).

12 Vale insistir no pensamento do autor: "A principal tarefa da política social não é mais a de reformar a sociedade, mas restaurar a autoridade dos pais e outros mentores que moldam os cidadãos [...]. A fonte de liberdade para os muito pobres da atualidade não é mais a oportunidade, mas a ordem. Para eles o caminho para avançar não é mais liberdade, mas obrigação" (Mead (1996, pp. 274-175).
13 Ver também Murray (2002). Vale insistir: "[...] a ética da underclass: pegue o que você quiser. Responda de modo violento a qualquer um que o antagonize. Despreze a cortesia, pois trata-se de fraqueza. Sinto orgulho em fraudar (furtar, mentir, explorar) com sucesso" (Murray, 1999, p. 14).

14 Robert Castel mostra que a questão social na Europa desponta em 1349 na Inglaterra, quando o rei Eduardo III promulga uma ordenança sobre o estatuto dos trabalhadores; na França, dois anos após, João II, dito o Bom, edita uma ordem real de combate à vadiagem, isto é, daqueles que podem mas não querem trabalhar, distinguindo-os dos inválidos e incapazes que necessitam e merecem proteção (1995a, p. 75).

15 Vale mencionar que as favelas ainda eram numerosas nos arredores de Paris e Marselha até 1964, quando uma lei obriga sua erradicação (Guerrand, 1999, p. 226).

16 Veja, entre outros, PAUGAM, Serge - La Societé Française et ses Pauvres, Paris, Presses Universitaires de France, 1993 e La Disqualification Sociale: Essai sur la Nouvelle Pauvreté, Paris, Presse Universitaires de France, 1991.

17 Ver também Donzelot e Roman, 1991, pp. 5-10.

18 Na mesma direção, ver também o penetrante estudo etnográfico de Laé e Murard (1995).

19 A literatura acerca do tema em pauta é vasta. Cf. Rey (1996), Body Gendrot (1993).

20 Dubet (1987). Ver também Dubet e Lapeyronnie (1992). Para uma visão dramática e desesperançosa a respeito desses grupos jovens, ver Lapeyronnie (1995, pp. 2-17).

21 Ver também Donzelot (1999).

22 Para uma análise que aponta as diferenças entre o gueto negro dos Estados Unidos e as periferias empobrecidas da França, bem como a atuação do poder público nesses países, ver Wacquant (1996b, pp. 234-274).

23 Ver, entre outros, Vários Autores (1995, principalmente, parte 1) e Madec e Murard (1995).

24 Cf. Paugam (1991), "Pauvreté et exclusion, la force des contraintes nationaux", em Paugam (1999), e Gaujelac e Leonetti (1994).

25 Silhuetas, indivíduos perdidos, extraviados, maltrapilhos, decompostos nos seus gestos, muitos inválidos. Castel faz alusão à pintura de Gerome Bosch que mistura corpos de contornos mal-definidos, unificados em movimentos que aludem à alegoria 
do sofrimento. Impossível deixar de associar essa descrição ao quadro de Jean Baptiste Debret, Primeiro impulso de virtude guerreira, de 1827, que abre o brilhante ensaio "Neoclassicismo e a escravidão” de Rodrigo Naves (1997). Na formação da sociedade francesa, observam-se elementos como a desqualificação e a perda de raízes, em vários momentos da expansão capitalista; no Brasil, prevaleceram o "travo", o "desacerto", a "dissolvência", a "atmosfera viscosa", o "falseamento", pois a estrutura social criada dentro do sistema escravista considera os trabalhadores, após a abolição, uma massa crescente de livres e pobres, socialmente desclassificados e inaptos para o trabalho, verdadeira ralé destituída de humanidade. Prepotência, arbítrio e violência permeiam toda a sociedade. Nas palavras de Rodrigo Naves: "com Debret a representação do Brasil urbano do começo do século XIX ganha uma nova dimensão, que a miséria contemporânea em parte ainda avaliza" (p. 116).

26 Redigindo de forma saudosa e comovente, Castel (1990) debruça-se sobre o mito de Tristão e Isolda, paixão impossível, tragédia do amor absoluto para mostrar os percursos da desfiliação.

27 Ver também Jones (1983).

28 Le Monde, edição de 18 de outubro de 1994, apud Fassin, 1996, p. 47.

29 Cf. Délégation Interministerielle de la Ville - DIV, s. d.

30 A literatura sobre RMI é vasta e polêmica. A título de exemplo, ver Castel e Laé (1992), e o número especial da Revue du Mauss, "Vers un revenu minimum inconditionnel?", Paris, n. 7, 1 semestre, 1996.

31 Retomo e resumo os argumentos publicados em Kowarick, 2002, pp. 26-30.

32 O termo "coitado" vem da palavra "coito", aquele que foi submetido à cópula carnal. Devo esta observação a Adrian Gurza Lavalle, feita durante o curso que proferi em 1997. Tal acepção está próxima da expressão usada por Roberto DaMatta (1990): “criamos até uma expressão grosseira para esse tipo de gente que tem que seguir imperativamente todas as leis: são 'os fodidos' do nosso sistema” (p. 199).

33 Vera Silva Telles, em artigo recente, também utiliza esses argumentos: "[...] nossas elites podem ficar satisfeitas com sua modernidade e dizer candidamente que a pobreza é lamentável, porém inevitável [...]. Nessa pobreza transformada em fato bruto da natureza há também o esvaziamento da função crítica das noções de igualdade e justiça" (1999, pp. 87-88).

\section{BIBLIOGRAFIA}

ABRAMOVITZ, Mimi \& WITHORN, Ann. (1998), "Playing by the rules: welfare reform and the new authoritarian State", in Adolph Reed Jr. (ed.), Without justice for all: the new liberalism and our retreat from racial equality, Boulder, Colo., Westview Press.

AFFICHAR, Joelle \& FOUCAULD, Jean Batiste de (orgs.). (1993), Justice sociale et inegalités. Paris, Esprit.

AULETTA, Ken. (1981), "A reporter at large (the underclass)". New Yorker, 16, 23 e 30 nov.

(1982), The underclass. Nova York, Random House.

AVENEL, Cyprien. (1997), "La question de l'underclass des deux cotés de l'Atlantique”. Sociologie du Travail, 2.

BODY GENDROT, Sophie. (1993), Ville et violences. Paris, Presses Universitaires de France.

BONELLI, Laurent. (2001), "Des quartiers en danger aux 'quartiers dangereux'”. Le Monde Diplomatique, Paris, fev.

BOURDIEU, Pierre (org.) (1993), La misère du monde. Paris, Le Seuil.

BRUNET, Jean-Paul. (1980), Saint Denis la Ville Rouge, 1890-1939. Paris, Hachette.

(1981), Un demi: siècle d'action municipale à Saint-Denis la Rouge, 18901930. Paris, Éditions Cujas, coleção Gral.

BURROUGHS, Charles. (1835), A discourse delivered in the chapel of the new alms-bouse, in Portsmouth, N.H. Dec. XV. MDCCCXXXIV. on the occasion of its being first opened for religious services. Portsmouth, N. H., J. W. Foster.

CALDEIRA, Teresa Pires do Rio. (1997), "Enclaves fortificados: a nova segregação urbana". Novos Estudos CEBRAP, 47. 
CARVALHO, José Murilo. (s. d.), "Interesse contra a cidadania", in Vários autores, Brasileiro Cidadão, São Paulo, Cultura.

CASTEL, Robert. (1990), "Le roman de la désaffiliation, à propos de Tristan et Iseut". Le Débat, 61, set.

(1991), "De l'indigence à l'exclusion, la sésaffiliation: précarité du travail et vulnérabilité relationnelle", in Jacques Donzelot (org.), Face à l'éxclusion le modèle français, Paris, Esprit.

(1993), "De l'exclusion comme état à la vulnérabilité comme Processus", in Joelle Affichar e Jean Batiste de Foucauld (orgs.), Justice sociale et inegalités, Paris, Esprit.

(1995a), Les métamorphoses de la question sociale: une chronique du salariat. Paris, Fayard.

(1995b), "Les pièges de l'exclusion". Lieu Social et Politiques, Revue Internationale d'Action Communautaire, 34.

(1999), "Les marginaux dans l'histoire", in Serge Paugam (org.), L'exclusion, L'état des savoirs, Paris, Éditions de la Decouverte.

CASTEL, Robert \& LAÉ, Jean François (orgs.) (1992), Le revenu minimum d'insertion: une dette sociale, Paris, L'Harmatan.

DAMATTA, Roberto. (1990), Carnavais, malandros e heróis: para uma sociologia do dilema brasileiro. 5 ed., Rio de Janeiro, Editora Guanabara.

DAMON, Julien. (1977), "Problèmes politiques et sociaux", Dossiers d'Actualité Mondiale, La politique de la ville, Paris, Le Documentation Française, 784, maio.

DELARUE, Jean Marie. (1991), Banlieu en difficulté: la rélegation. Paris, Syros.

DÉLÉGATION Interministerielle de la Ville - DIV. (s. d.), Repères, 2000 - 2006, "Une nouvelle ambition de la politique de la ville", Paris, Les Éditions de la DIV.
DONZELOT, Jacques. (1996), "L’avenir du social". Esprit, 219, mar.

(1999), "La nouvelle question urbaine". Esprit, 258, nov.

. (2001), "Sortie de la dépendance et utilité sociale", in Jacques Donzelot e Marie Christine Jaillet, La nouvelle question urbaine: actes du séminaire, PUCA, Ministère de L'équipement, des Transports et du Logement, Actes du Séminaire $(1999 / 2000)$.

DONZELOT, Jacques \& ESTEBE, Philipe. (1991), L'état animateur: essai sur la politique de la ville, Paris, Esprit, Paris.

DONZELOT, Jacques \& JAILLET, Marie Christine. (2001), La nouvelle question urbaine: actes du séminaire. PUCA, Ministère de L'équipement, des Transports et du Logement, Actes du Séminaire (1999/2000).

DONZELOT, Jacques \& ROMAN, Joel. (1991), "Le déplacement de la question sociale", in Jacques Donzelot (org.), Face l'exclusion: le modèle français, Paris, Esprit.

DUBET, François. (1987), La galère, jeunes en survies. Paris, Fayard.

DUBET, François \& LAPEYRONNIE, Didier. (1992), Les quartiers d'exil. Paris, Seuil.

FASSIN, Didier. (1996), "Exclusion, underclass, marginalidad: figures contemporaines de la pauvreté urbaine en France, aux États Unis et en Amerique Latine". Revue Française de Sociologie, XXXVII.

FORRESTER, Viviane. (1997), O horror econômico. São Paulo, Editora da Unesp.

FOURCAUT, Annie. (1986), Bobigny, banlieu rouge. Paris, Les Éditions Ouvrières \& Presses de la Fondation Nationale de Sciences Polítiques.

FRÉTIGNÉ, Cédric. (1999), Sociologie de l'exclusion. Paris, L'Harmattan, "Logiques Sociales".

GANS, Herbert J. (1994), "Positive functions of the undeserving poor: uses of the underclass in America”. Politics E Society, 22 (3), set. 
(1995), The war against poverty: the underclass and antipoverty politics. Nova York, Basic Books.

GAUJELAC, Vicent de \& LEÓNETTI, Isabele Taboada. (1994), La lutte des places: insertion et désinsertion. Paris, Desclée Brou.

GENDROT, Sophie. (1993), Ville et violences. Paris, Presses Universitaires de France.

GUERRAND, Roger Henri. (1999), "Histoire des Taudis", in Serge Paugam (org.), L'éxclusion, l'état du savoir, Paris, Éditions de la Decouverte.

HARRINGTON, Michael. (1962), The other America: poverty in the United States. Nova York, MacMillan.

. (2002), "The other America revisited: a more difficult poverty". Vew Perspectives Quarterly, 4 (1), mar.

HEISLER, Barbara Schmitter. (1991), “A comparative perspective on the underclass: questions of urban poverty, race, and citizenship". Theory and Society, 20 (4), ago.

HOGGART, Richard. (1970), La culture du pauvre. Paris, Minuit.

JENKS, Christopher. (1985), "How poor are the poor". New York Review of Books, maio.

JENKS, Christopher \& PETERSON, Paul E. (1991), The urban underclass. Washington, DC, Brookings Institution.

JONES, Gareth Stedman. (1983), Languages of class, studies in English working class bistory, 1832-1982. Cambridge, Cambridge University Press.

KATZ, Michael B. (1993), "The urban 'underclass' as a metaphor of social transformation", in Michael B. Katz, The "underclass" debate: views from history, Princeton, New Jersey, Princeton University Press.

KOWARICK, Lúcio. (1975), Capitalismo e marginalidade na América Latina. 1 ed., Rio de Janeiro, Paz e Terra.
(2001), "Vulnerabilidade social y económica: trayectorias del tema en Estados Unidos, Francia y Brasil", in Marco A. Caldeira Molgora e Willem Assies, Ciudadanía, cultura política y reforma del in América Latina, XXIII Coloquio de Antropología y Historia Regionales, El Colegio de Michoacan, México, 24-26 out., pp. 103-141.

. (2002), "Viver em risco: sobre a vulnerabilidade no Brasil urbano". Novos Estudos, 63: pp. 9-29, jul.

LABBENS, Jean. (1969), Le quart-monde, la pauvreté dans la societé industrielle: étude sur le sous-proletariat dans la région parisienne. 95 Pierrelaye, Éditions Science et Service.

. (1978), Sociologie de la pauvreté. Paris, Gallimard.

LAÉ, Jean François \& MURARD, Numa. (1995), Les récits du malheur. Paris, Descartes et Cie.

LAPEYRONNIE, Didier. (1995), "L'exclusions et le mepris". Les Temps Modernes, Paris.

LE MONDE. (1994), "Edição especial de 18 de out.

LEWIS, Oscar. (1961a), Antropologia de la pobre$z a$ : cinco familias. México, Fondo de Cultura Económica.

(1961b), The children of Sanchez. Nova York, Random House.

(1965), La vida: Puerto Rico family in the culture of poverty. Nova York, Vintage Books.

. (1966), "The culture in poverty". Scientific American, 15 (4), out.

LENOIR, René. (1974), Les exclus: un français sur dix. Paris, Le Seuil.

MADEC, Annich \& MURARD, Numa. (1995), Citoyennetés et politiques sociales. Paris, Flammarion.

MAGRI, Suzana \& TOPALOV, Christien (orgs.). (1990), Villes ouvrières, 1900-1950. Paris, L'Harmattan. 
MARKS, Carol. (1991), "The urban underclass". Annual Review of Sociology, 17.

MARTINS, José de Souza. (1997), Exclusão social e a nova desigualdade. São Paulo, Paulus.

MEAD, Lawrence M. (1986), Beyond entitlement: the social obligations of citizenship. Nova York, The Free Press.

(1996), "Raising work levels among the poor", in Michael R. Darby (ed. ), Reducing poverty in America: views and approaches, Thousand Oaks, Calif., Sage Publications.

MINGIONE, Enzo (ed.). (1996), Urban poverty and the underclass. Oxford, Blackwell.

MINISTÈRE de L'equipement, des Trasports et du Logement. (2001), "Le politique de la ville: une comparaison entre les USA et la France". Plus Ville Internationale, 56, maio.

MOYNIHAN, Patrick. (1965), The negro family: the case for national action. Washington, D.C., Office of Policy, Planning and Research, U.S., Department of Labor.

MURARD, Numa. (1995), "L'esprit de la citoyenneté”, in Vários autores, Pauvres ou citoyens? Faites vos prewves, Repport de recherche pour le Fonds d'Action Sociale, Paris, maio.

MURRAY, Charles. (1994), Losing ground, American social policy, 1950-1980. 2 ed., Nova York, Basic Books (1 ed. 1984).

. (1996), "Reducing the poverty and reducing the underclass", in Michael R. Darby (ed.), Reducing poverty in America: views and approches, Thousand Oaks, Calif., Sage Publications.

. (1999), "And now for the bad knews". Society, 37 (1), nov.-dez.

. (2002), "The underclass revisited", Trabalho apresentado para American Enterprise Institute for Public Rescarch, 11 mar.

MYRDAL, Gunnar. (1994), An American dilemma: the negro problem and modern demo- cracy. Nova York/Londres, Harper/Brother Publishers (com assistência de Richard Sterner e Arnold Rose).

(1963), The challenge to affluence. Nova York, Pantheon Books.

NASCIMENTO, Elimar Pinheiro. (1994a), "A exclusão social na França e no Brasil: situações (aparentemente) invertidas, resultados (quase) similares", in Elias Dinis, José Sérgio Leite Lopes e Reginaldo Prandi, O Brasil no rastro da crise, São Paulo, Anpocs/Hucitec, Ipea.

NAVES, Rodrigo. (1997), A forma dificil: ensaios sobre arte brasileira. 2 ed., São Paulo, Ática.

NOBLE, Charles. (1997), Welfare as we knew it: a political history of American welfare State. Nova York/Oxford, Oxford University Press.

OLIVEIRA, Francisco de. (1999), "Privatização do público, destituição da fala e anulação da política pública: totalitarismo neoliberal", in Francisco de Oliveira e Maria Célia Paoli, Os sentidos da democracia: políticas do discurso e hegemonia global, Petrópolis, Vozes.

PAUGAM, Serge. (1991), La desqualification sociale: essai sur la nouvelle pauvreté. Paris, Presses Universitaires de France.

(1993), La societé française et ses pauvres. Paris, Presses Universitaires de France.

(org.). (1999), L'éxclusion, l'état du savoir. Paris, Éditions de la Découverte.

PRÉTECEILLE, Edmond. (1998), "De la ville divisée à la ville éclatée: questions et categories de recherche", in N. May; J. Landrieu e T. Spector (orgs.), La ville éclatée, Paris, Éditions de L'Aube.

PROCACCI, Giovanna. (1996), "Exclus ou citoyens? Les pauvres et les sciences sociales". Archives Européennes de Sociologie, XXXVI (2). 
PRONIER, Raymond. (1983), Les municipalités communistes: bilan de 30 annés de gestion. Paris, Baleand.

RAINWATER, Lee \& YANCEY, William L. (ed.). (1967), The Moyniham report and the politics of controversy. Cambridge, MIT Press.

REY, A. (ed.). (1992), Dictionnaire bistorique de la langue française. Paris, Dictionnaire Le Robert.

REY, Henri. (1996), La peur des banlieus. Paris, Presses de Sciences Po.

ROBINSON, Fred \& GREGSON, Nicky. (1992), "The 'underclass': a class apart?". Critical Social Theory, 12 (1).

ROSANVALLON, Pierre. (1995), La nouvelle question sociale: repenser l'état providence. Paris, Seuil.

ROULEAU BERGER, L. (1992), La ville intervalle. Paris, Meridiens/Klincksiech.

RUSSEL, George. (1977), "The American underclass". Time Magazine, 29 ago.

RYAN, William. (1976), Blaming the victim. Nova York, Ventage Books.

SANTOS, Wanderley Guilherme. (1994), "Fronteiras do estado mínimo: indicações sobre o híbrido institucional no Brasil", in Razões da desordem, Rio de Janeiro, Rocco.

SCHWARCZ, Lilia K. Moritz. (2001), "Dando nome às diferenças", in Eni de Mesquita Samara (org.), Racismo E racistas, São Paulo, Humanitas, FFLCH/USP.

SCHWARZ, Roberto. (1990), Um mestre na periferia do capitalismo, Machado de Assis. São Paulo, Livraria Duas Cidades.

SILVA TELLES, Vera. (1999), "A 'nova questão social' brasileira: ou como as figuras do nosso atraso viraram símbolo de nossa modernidade". Cadernos CRH, 30/31, Salvador, jan.-dez.
SILVER, Hilary. (1994), "Exclusion sociale et solidarité sociale: trois paradigmes". Revue Internationale du Travail, 133 (5-6).

(1996), "Culture, politics and national discourse of the new urban pour", in Enzo Mingione, Urban poverty and the underclass, Oxford, Blackwell.

(1999), "National conceptions of the new urban poverty, social structural change". International Journal of Urban and Regional Research, 17 (3), set.

THOMPSON, Edward P. (1997), La formación historica de la classe obrera, Inglaterra: 1780-1832. Barcelona, Editorial Laia.

TOPALOV, Christien. (1994), Naissance du chômeur, 1882-1910. Paris, Ablin Michal.

TOURAINE, Alain. (1991), "Face a l'exclusion", in Vários autores, Citoyenneté et urbanité, Paris, Esprit.

. (1992), "Inégalités de la société industrielle", in Joëlle Affichard e Jean-Baptiste de Foucauld (orgs.), Justice sociale et inegalités, Paris, Esprit.

VALLADARES, Lícia. (1994), "Cem anos pensando a pobreza (urbana) no Brasil", in Renato R. Boschi (org.), A construção do espaço público no Brasil, Rio de Janeiro, Rio Fundo Editora.

VÁRIOS AUTORES. (1995), Pauvres ou citoyens? Faites vos preuves, Repport de recherche pour le Fonds d'Action Sociale, Paris, maio.

VÁRIOS AUTORES. (1996), "Vers um revenu minimum inconditionnel?". Revue du Mauss, 7, $1^{\circ}$ semestre.

VÁRIOS AUTORES. (1998), Les quartiers dont on parle. Paris, Éditions de l'Aube.

WACQUANT, Löic. (1996a), "L’underclass urbain dans l'imaginaire social et scientifique américain", in Serge Paugam (org.), L'exclusion, état des savoir. Paris, Éditions de la Decouverte. 
. (1996b), "Red belt, black belt: racial division and the State in French urban periphery and the American ghetto", in Enzo Migione (ed.), Urban poverty and the underclass, Oxford, Blackwell.

WILSON, William Julius. (1987), The truly disadvantaged the inner city: the underclass and public policy. Chicago, The University of Chicago Press.

(1990), "Social theory and public agenda research: the challenge of studying Inner - city social dislocation". Annual Meeting of the American Sociological Association, Presidential Address, 12 ago.

. (1991-1992), "Another look at the truly disadvantaged". Political Science Quarterly, 106 (4).

(ed.). (1993), The ghetto underclass. Londres, Sage.

. (1997), When work disappears: the world of the new urban poor. Nova York, Alfred A. Knopf.

(1999), The bridge over the racial divide: rising inequality and coalition politics. Berkeley/Los Angeles/Londres, University of California Press. 


\section{SOBRE A VULNERABILIDADE SOCIOECONÔMICA E CIVIL: ESTADOS UNIDOS, FRANÇA E BRASIL}

Lúcio Kowarick

\section{Palavras-chave}

Exclusão e vulnerabilidade social; Sesafiliação; underclass; (Sub)cidadania.

O artigo analisa a evolução do debate acerca da vulnerabilidade socioeconômica nos Estados Unidos e na França, com comentários finais sobre a atualidade brasileira. No caso norte-americano, a discussão é abertamente política-ideológica culpar ou não as vítimas por sua situação de marginalização e anomia - e centra-se em torno do conceito de underclass, o que leva alguns autores a responsabilizar os programas de bem-estar no fomento da ociosidade e desorganização familiar. No caso francês, ao contrário, seguindo a tradição republicana, os diagnósticos e as propostas enfatizam a necessidade de uma forte presença estatal, que deve fornecer os meios de (re) inserção dos grupos marginalizados. A polêmica se dá em torno dos conceitos de exclusão social e desafiliação. O ensaio não visa realizar um balanço crítico da literatura, mas, a partir de obras seminais, mostrar os parâmetros que essa problemática teórica e empírica adquire em função das especificidades de cada ambiente político nacional; daí as observações finais sobre a sociedade brasileira.

\section{À PROPOS DE LA VULNÉRA- BILITÉ SOCIO-ÉCONOMIQUE ET CIVILE: ÉTATS-UNIS, FRANCE ET BRÉSIL}

Lúcio Kowarick

\section{Key words}

Mots-clés : Exclusion et vulnérabilité sociale ; Désaffiliation ; underclass; (Sous)citoyenneté.

L'article porte sur le débat à propos de la vulnérabilité socio-économique aux Étas-Unis et en France, avec des conclusions commentées à propos de l'actualité brésilienne. Dans le cas nord-américain, la discussion est ouvertement politique et idéologique - condamner ou pas les victimes à cause de leur situation de marginalité et d'anomie - et est centrée sur le concept de underclass, ce qui conduit certains acteurs à responsabiliser les programmes de bien-être dans l'encouragement du fainéantise et de la désorganisation familiale. À l'inverse, dans le cas français, suivant la tradition républicaine, les diagnostiques et les propositions mettent l'accent sur le besoin d'une forte présence de l'État, qui doit fournir les moyens de (re) insertion des groupes marginalisés. Le polémique a lieu par rapport aux concepts d'exclusion sociale et de desaffiliation. Cette étude n'a pas pour but d'établir un bilan critique de la littérature, mais de montrer, à partir des œuvres séminales, les paramètres que cette problématique théorique et empirique acquiert en fonction des spécificités de chaque environnement politique national ; d'où les observations finales à propos de la société brésilienne.

\section{ABOUT SOCIOECONOMIC AND CIVIL VULNERABILITY: THE UNITED STATES OF AMERICA, FRANCE AND BRAZIL}

Lúcio Kowarick

\section{Mots-clés}

Keywords: Exclusion and social vulnerability; Defiliation; Underclass, (Under)citizenship

The article analyses the evolution of the debate on socioeconomic vulnerability both in the United States of America and in France, as well as presenting final comments on the Brazilian present time. In the NorthAmerican study, the discussion is openly political-ideological - making guilty or not the victims for their marginalization and anomy - making use of the concept of underclass, what has made some authors regard the so-called well-being programs as responsible for promoting idleness and family disorganization. In the French study, on the contrary and following the republican tradition, both the diagnosis and proposals emphasize the need of strong state presence to provide means of (re)inserting the marginalized groups. Polemic arises around concepts such as social exclusion and defiliation. The essay doesn't aim at making a critical balance of literature, but making use of seminal works it intends to show the parameters acquired by the theoretical and empirical problem depending on the particularities of each national political ambience; that is when final comments on the Brazilian society are made. 